\section{Diagnostic and Therapeutic Role of CT-Guided Stereotactic Surgery in the Management of Intracranial Tuberculomas}

\section{İntrakranial Tüberkülomaların Tanı ve Tedavisinde Bilgisayarlı Tomografi Rehberliğinde Stereotaktik Cerrahinin Rolü}

\begin{abstract}
AIM: CT-guided stereotactic methods have long been used for the diagnosis and treatment of intracranial masses. Intracranial tuberculoma is a rare form of extrapulmonary tuberculosis. Histological confirmation is the gold standard for a correct diagnosis. However, histopathological diagnosis and excision of these lesions have advantages over open surgical methods. This study presents our experience on the use of stereotactic biopsy and excision in the management of intracranial tuberculomas.
\end{abstract}

MATERIAL and METHODS: Thirteen patients with intracranial masses underwent stereotactic procedures for tissue samples to establish histopathological diagnosis. In 6 suitable patients, stereotactic microsurgical excision was performed for both diagnostic and therapeutic purposes, whereas only stereotactic biopsy was conducted in the remaining subjects.

RESULTS: The tuberculoma diagnosis was established in 12 out of 13 cases $(92 \%)$. Seizure control was achieved in all patients admitted with a history of seizures. There was no procedure-related mortality, none of the patients suffered permanent disability and most procedures were uneventful. Total resection without any residual mass was done. All patients responded to antituberculous treatment with complete lesion disappearance.

CONCLUSION: These findings suggest that CT-guided stereotactic surgery of intracranial tuberculomas has advantages over other methods, with a potential to become the first-line modality, particularly as a diagnostic tool, in the management of these lesions.

KEYWORDS: Tuberculoma, Stereotactic surgery, Management, Histopathological diagnosis

ÖZ

AMAÇ: Bilgisayarlı tomografi rehberliğinde stereotaktik yöntem intrakranial kitlesel lezyonların tanı ve tedavisinde uzun süredir kullanılmaktadır. İntrakranial tüberküloma ekstrapulmoner tüberkülozun nadir bir formudur ve doğru tanıda histopatolojik tanı altın standarttır. Bununla birlikte intrakranial tuberküloma lezyonlarının açık cerrahi yöntemle çıkarılmalarının ve histopatolojik örnekleme yapılmasının bir çok dezavantajı vardır. Çalışmamızda intrakranial tüberkülomaların tedavisinde stereotaktik biyopsi ve stereotaktik mikrocerrahi rezeksiyon deneyimlerimiz sunulmuştur.

YÖNTEM ve GEREÇ: İntrakranial kitlesel lezyonları olan 13 olguya histopatolojik tanı için stereotaktik yöntem uygulanmıştır. Uygun olan $(n=6)$ olguda hem tanı ve hem de tedavi için stereotaktik mikrocerrahi rezeksyon uygulamış, bununla birlikte 7 olguda sadece tanı amacıyla stereotaktik biyopsi işlemi uygulanmıştır.

BULGULAR: Olası tüberkülomalı 13 olgunun biri dıșında 12 olguda histopatolojik olarak tuberküloma tanısı konmuştur (\%92). Nöbet öyküsü olan bütün olgularda nöbet kontrölü sağlanmıştır. Stereotaktik işleme bağlı ölüm ve kalıcı sakatlık saptanmadı. Stereotaktik mikrocerrahi rezeksiyon uygulanan hastaların hepsinde total rezeksiyon uygulandığı ve rezidüel kitlenin olmadiğı saptandı. Tüm hastalarda antitüberküloz tedavi süresinde lezyonların tamamen yok olduğu saptandi.

SONUÇ: Çalışmamızın sonuçları göstermiştirki İntrakranial tüberkülomaların tanı ve tedavisinde bilgisayarlı tomografi rehberliğinde stereotaktik cerrahinin diğer yöntemlere bir çok üstünlüğü vardır. Intrakranial tüberküloma lezyonlarının tedavisinde ve özellikle de tanısında ilk sırada düşünülmesi gereken bir yöntemdir.

ANAHTAR SÖZCÜKLER: Tüberküloma, Stereotaktik cerrahi, Tedavi, Histopatolojik tanı

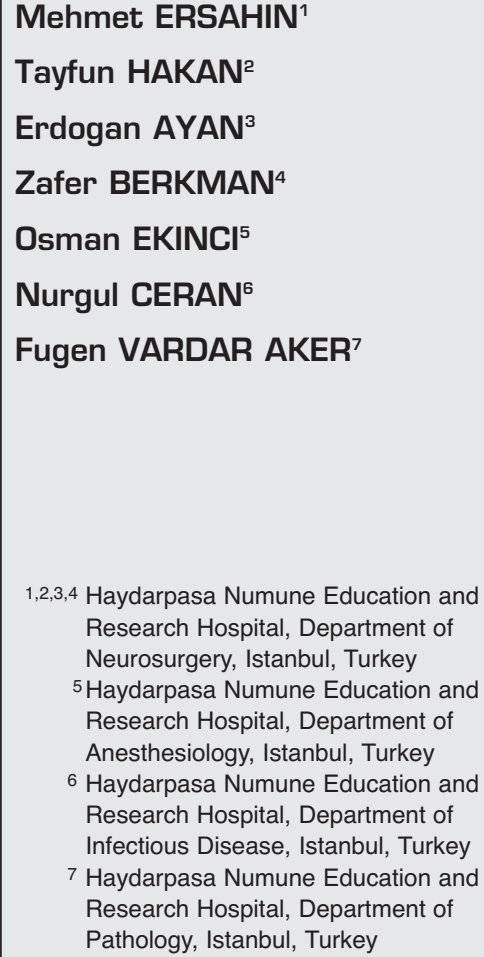
Research Hospital, Department of Neurosurgery, Istanbul, Turkey 5 Haydarpasa Numune Education and Research Hospital, Department of Anesthesiology, Istanbul, Turkey

6 Haydarpasa Numune Education and Research Hospital, Department of Infectious Disease, Istanbul, Turkey 7 Haydarpasa Numune Education and Research Hospital, Department of Pathology, Istanbul, Turkey

Received : 15.03.2010

Accepted : 15.04.2010

Correspondence address: Mehmet ERSAHIN

Altaycesme Mah. Sarigul Sok.

Kuralkan Apt. A1 Blok, Daire: 2 34840 Maltepe, Istanbul, TURKEY

Phone : +90 5423443373

Fax : :902163360565

E-mail : drmehmetersahin@gmail.com 


\section{INTRODUCTION}

Although an ancient disease, tuberculosis remains a major global public health issue $(14,15,22$, 24,25). Central nervous system tuberculosis is a serious form of extrapulmonary tuberculosis affecting approximately $10 \%$ of tuberculosis patients and intracranial tuberculomas are present approximately in $1 \%$ of patients with CNS tuberculosis (24). Tuberculoma is a granulomatous inflammatory process mimicking neoplasms and other inflammatory masses $(3,6,25)$.

Intracranial tuberculoma has a relatively higher incidence in the developing and underdeveloped countries than in the developed world. Although clinical evaluation combined with modern neuroimaging techniques may be sufficient to establish the diagnosis, histopathological examination remains the gold standard to increase diagnostic accuracy and to avoid inappropriate treatment $(3,6,25)$. However, deep-seated localization is mostly a major challenge in obtaining biopsy material.

Surgical excision and prolonged antituberculous treatment is the treatment of choice for tuberculoma lesions $(6,24,25)$. Although successful in a number of cases, open surgical treatment is associated with excessive surgical trauma $(6,25)$. On the other hand, CT-guided stereotactic surgery has firmly established itself as a safe and reliable technique in obtaining histological diagnosis of intracranial masses. This modality may not only aid in the diagnosis of intracranial tuberculomas, but in their management as well, particularly when they are deep seated, small and/or situated in the eloquent areas of the brain $(4,22,25)$.

In this study, we present our experience with 13 tuberculoma patients that underwent stereotactic microsurgical resection and/or stereotactic biopsy using the Leksell frame, in an attempt to discuss potential indications, results and limitations of this technique in this particular form of intracranial masses.

\section{MATERIAL and METHODS}

A total of 307 stereotactic procedures have been performed in our institution between March 1997 and March 2009, including 13 patients diagnosed with intracranial tuberculomas. These 13 patients can be categorized into two groups based on the procedure they underwent: (i) CT-guided stereotactic localization, craniotomy and excision of the mass $(n=6)$, or (ii) CT-guided stereotactic biopsy only $(n=7)$. Clinical characteristics of the patients are given in Table I. Patients were followed for a mean duration of $83.5 \pm 35.5$ months.

Patients that underwent a stereotactic procedure for diagnostic and therapeutic purposes $(n=6)$ had intracranial mass lesions on CT and MRI. Although one of these patients had a mass suspicious of tuberculoma and an uncertain history of pulmonary tuberculosis, other patients have no clinical evidence of tuberculosis. Five of these patients presented with generalized seizures and a solitary small lesion in close relation to the sensorimotor cortex, whereas the other patient had hemiparesis and symptoms of increased intracranial pressure. The size of the masses ranged between 10 and $30 \mathrm{~mm}$.

A total of seven patients not suitable for stereotactic microsurgery underwent stereotactic biopsy to histologically establish the diagnosis. One patient had an uncertain history of pulmonary tuberculosis and another patient had an uncertain family history for this disease. Five patients had multiple 5 to $10 \mathrm{~mm}$ sized supratentorial and infratentorial lesions with contrast enhancement and two had solitary lesions. One of the solitary lesions was deep seated and the other was cystic and located at the third ventricle. Stereotactic biopsy was performed in these 7 patients since clinical evidence was not sufficient to justify the definitive diagnosis of tuberculoma requiring antituberculous treatment (ATT).

\section{Operative technique}

Stereotactic procedures were performed using the Leksell Stereotactic system and the General Electric CT scanner.

CT-guided stereotactic localization, craniotomy and mass excision

The stereotactic frame was applied under local anesthesia, paying careful attention to the pin insertion sites so that they would not encroach upon the operative area. After calculation of the target coordinates, the patient was taken to the operating room for the surgical procedure, which was performed under general anesthesia. A small patch of hair was shaved over the operative site and the 
Table I: Clinical Characteristics of Patients

\begin{tabular}{|c|c|c|c|c|c|c|c|}
\hline $\begin{array}{l}\text { Pt. ID } \\
\text { of }\end{array}$ & $\begin{array}{l}\text { Age/ } \\
\text { Sex }\end{array}$ & $\begin{array}{c}\text { Stereotactic } \\
\text { procedure }\end{array}$ & $\begin{array}{l}\text { Radiological } \\
\text { findings }\end{array}$ & Localization & $\begin{array}{c}\text { Clinical } \\
\text { presentation }\end{array}$ & $\begin{array}{l}\text { History of } \\
\text { tuberculosis }\end{array}$ & $\begin{array}{l}\text { Duration } \\
\text { follow-up }\end{array}$ \\
\hline GD & $17 / \mathrm{F}$ & Excision & $\begin{array}{c}\text { Solitary multiloculated } \\
\text { mass with contrast } \\
\text { enhancement }\end{array}$ & R temporal & Seizure & None & $10 \mathrm{y}$ \\
\hline KG & $42 / \mathrm{M}$ & Excision & $\begin{array}{c}\text { Solitary bilobulated mass } \\
\text { with contrast } \\
\text { enhancement }\end{array}$ & L motor cortex & Seizure & Pulmonary & $7 \mathrm{y}$ \\
\hline NA & $70 / \mathrm{M}$ & Excision & $\begin{array}{l}\text { Solitary mass with } \\
\text { contrast enhancement }\end{array}$ & L motor cortex & $\mathrm{R}$ hemiparesis & None & $64 \mathrm{mo}$ \\
\hline AU & $35 / F$ & Excision & $\begin{array}{l}\text { Solitary mass with } \\
\text { contrast enhancement }\end{array}$ & $\mathrm{R}$ premotor cortex & Seizure & None & $11 \mathrm{y}$ \\
\hline $\mathrm{HE}$ & $19 / \mathrm{F}$ & Excision & $\begin{array}{l}\text { Solitary mass with } \\
\text { contrast enhancement }\end{array}$ & L temporal & Seizure & None & $6 y$ \\
\hline HSM & $10 / \mathrm{M}$ & Excision & $\begin{array}{c}\text { Solitary mass with } \\
\text { contrast enhancement }\end{array}$ & $\mathrm{R}$ motor cortex & Seizure & $\begin{array}{l}\text { Family } \\
\text { history }\end{array}$ & $42 \mathrm{mo}$ \\
\hline $\mathrm{EC}$ & $32 / \mathrm{M}$ & Biopsy & $\begin{array}{l}\text { Multiple lesions with } \\
\text { contrast enhancement }\end{array}$ & Multiple & Hemiparesis & None & $5 y$ \\
\hline NA & $30 / \mathrm{F}$ & Biopsy & $\begin{array}{l}\text { Multiple lesions with } \\
\text { contrast enhancement }\end{array}$ & Multiple & Hemiparesis & $\begin{array}{l}\text { Pulmonary } \\
\text { (uncertain) }\end{array}$ & $9 y$ \\
\hline OB & $11 / \mathrm{M}$ & Biopsy & $\begin{array}{l}\text { Cystic lesion with } \\
\text { contrast enhancement }\end{array}$ & Third ventricle & Raised ICP & None & $11 \mathrm{y}$ \\
\hline MT & $61 / \mathrm{M}$ & Biopsy & $\begin{array}{l}\text { Multiple lesions with } \\
\text { contrast enhancement }\end{array}$ & Multiple & $\begin{array}{l}\text { 7th cranial } \\
\text { nerve palsy }\end{array}$ & None & $8 \mathrm{y}$ \\
\hline SC & $40 / \mathrm{F}$ & Biopsy & $\begin{array}{l}\text { Multiple lesions with } \\
\text { contrast enhancement }\end{array}$ & Multiple & Seizure & None & $9 y$ \\
\hline SP & $58 / \mathrm{F}$ & Biopsy & $\begin{array}{c}\text { Giant lesion with contrast } \\
\text { enhancement }\end{array}$ & Thalamus & Hemiparesis & None & $3 y$ \\
\hline SB & $60 / F$ & Biopsy & $\begin{array}{l}\text { Multiple lesions with } \\
\text { contrast enhancement }\end{array}$ & Multiple & Fever & $\begin{array}{l}\text { Family } \\
\text { history } \\
\text { (uncertain) }\end{array}$ & $32 \mathrm{mo}$ \\
\hline
\end{tabular}

entire head and the frame was placed and draped in a sterile fashion. All cases then underwent standard microsurgical stereotactic procedure as previously described elsewhere $(10,18,19)$.

\section{CT-guided stereotactic biopsy}

Standard CT-guided stereotactic biopsy procedure was performed under local anesthesia as previously described elsewhere $(2,12)$. A sedan type needle was used to obtain the biopsy specimen and the tissue was urgently processed after smear preparation. In two cases, a spiral needle was also required to obtain adequate biopsy specimen since sufficient tissue material could not be obtained by the cup forceps. One patient underwent cyst aspiration in addition to biopsy. Sampling was done from supratentorial lesions in all these patients.

\section{RESULTS}

CT-guided stereotactic localization, craniotomy and mass excision $(n=6)$

Histopathological diagnosis of all excisional biopsy specimens was consistent with tuberculoma. All specimens were negative for $M$. tuberculosis culture but acid-fast staining demonstrated the presence of bacilli in one of the samples. CT scans performed within 24 hours after the procedure confirmed total excision of the mass and absence of any hemorrhage. Seizure control was achieved in all 
five patients admitted with seizures and antiepileptic agents were gradually discontinued. Hemiparesis of one patient worsened after the excision of a parietal mass, but weakness resolved after steroid therapy. There was no procedurerelated mortality and none of the patients suffered permanent disability. All cases received approximately 18 months of antituberculous treatment, all lesions disappeared and none of the patients had tuberculoma recurrence during the follow-up period. Antituberculous treatment was well tolerated by all patients, except for a transient increase in liver enzymes in one patient necessitating temporary interruption of the treatment. All cases had negative serology for human immunodeficiency virus (HIV). Examples of MRI and CT images before and after the procedure are given in Figure 1.

\section{CT-guided stereotactic biopsy $(n=7)$}

Histopathological examination of stereotactic biopsy specimens was consistent with tuberculoma in 6 patients, whereas one patient had chronic inflammation with gliosis histologically. The latter case had numerous masses of approximately $5 \mathrm{~mm}$ in size with abundant contrast enhancement. Definitive diagnosis of tuberculoma was based on clinical features, cerebrospinal fluid changes, and imaging characteristics in that particular patient, and the lesion responded to antituberculous treatment. Aspiration material from the cyst was positive for M. tuberculosis culture and acid-fast staining for bacilli in the patient with cystic tuberculoma. On the other hand, specimens from other patients were all negative for culture and direct staining.

In one patient, a small asymptomatic hematoma developed at the site of biopsy, but this hematoma did not increase in size and resolved spontaneously. There was no procedure-related mortality and none of the patients suffered permanent disability due to the CT-guided stereotactic biopsy procedure. In another patient, a seizure localized to the right arm developed during the placement of the stereotactic frame, which was controlled by diazepam infusion. This case had history of seizures prior to the procedure. However, seizures localized to the right
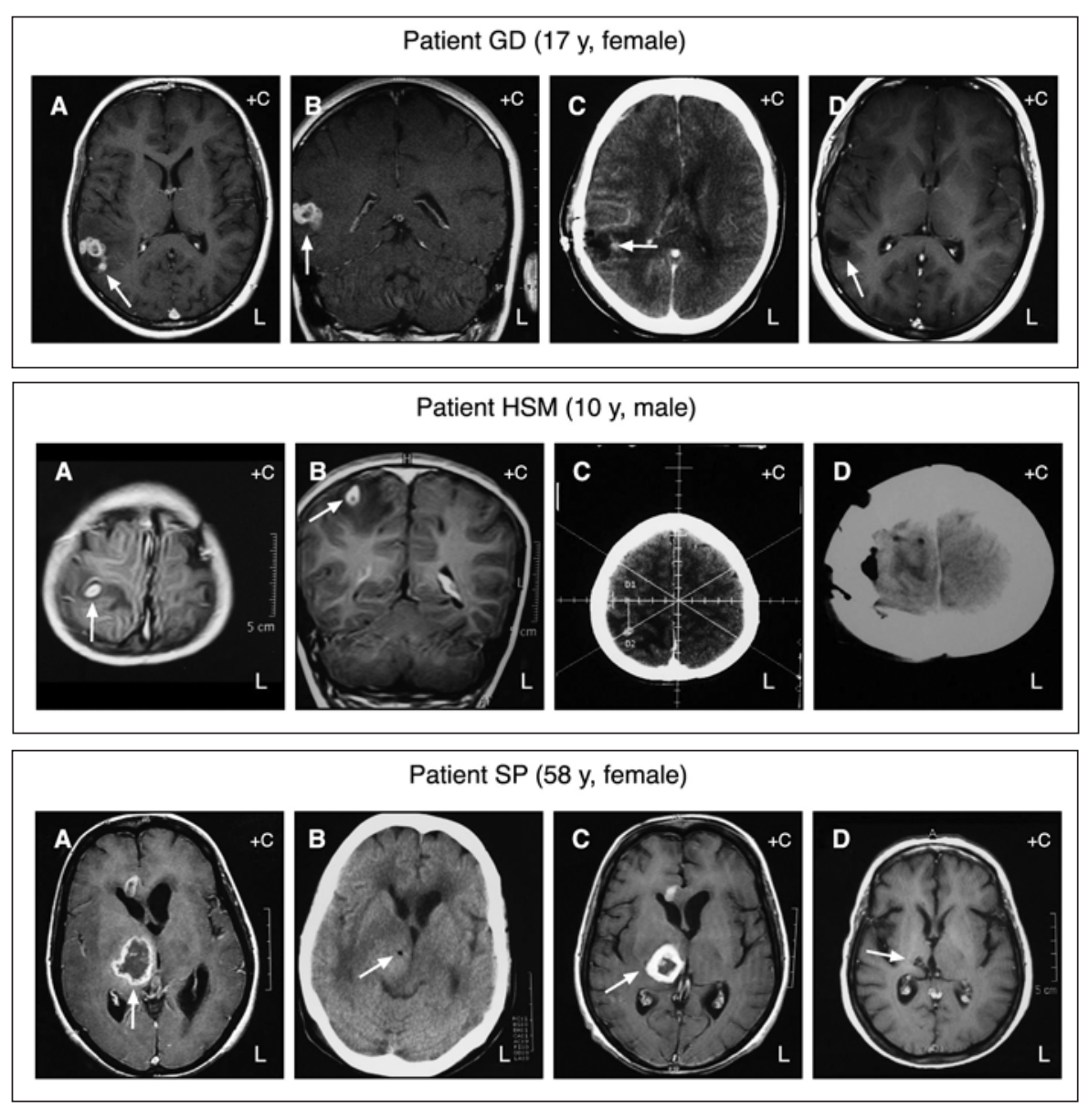

Figure 1: Examples of MRI and CT images.

Patient GD underwent stereotactic microsurgical resection: $A$ and $B$, preoperative contrast MRI; C and D, CT with contrast at early postoperative period and at 7 years after the procedure, respectively.

Patient HSM underwent stereotactic microsurgical resection: $A$ and $B$, preoperative contrast MRI; $C$ and D, CT with contrast during the procedure and at early postoperative period, respectively.

\section{Patient SP underwent} stereotactic biopsy: A, preoperative contrast MRI; $\boldsymbol{B}$, early postoperative CT without contrast; $C$, contrast MRI 3 months after the procedure; and $D$, contrast MRI at 3 years. 
arm decreased in frequency during the follow-up period and finally disappeared, allowing the discontinuation of antiepileptic treatment. Episodes of seizures were not seen in other patients. All patients received approximately 24 months of ATT and the treatment was well tolerated. Transient dose reductions were necessary in one patient due to renal failure and dialysis treatment. All masses disappeared during the follow-up period and no recurrence was observed. All patients were HIV negative. Examples of MRI and CT images before and after the procedure are given in Figure 1.

\section{DISCUSSION}

Tuberculosis continues to be an important health problem among underdeveloped populations of the world and in areas with a high prevalence of human immunodeficiency virus and alcohol or intravenous drug abuse (11, 14, 15). Central nervous system tuberculosis is a serious form of extrapulmonary tuberculosis; and although rare, intracranial tuberculomas are present approximately in $1 \%$ of patients with CNS tuberculosis (24). In developing countries, 5 to $8 \%$ of the space-occupying lesions of the central nervous system are tuberculomas (6).

Intracranial tuberculomas are mostly diagnosed based on clinical features, cerebrospinal fluid changes, and imaging characteristics; therefore, antituberculous treatment is usually administered on a presumptive basis $(5,14,15,31,32,35)$. Bacteriological conformation is not possible for the majority of patients as serological tests do not have sufficient sensitivity and specificity (24, 32). Radiological methods are also of limited use. Although CAT (computerized axial tomography) scanning is a non-invasive technique useful in the follow-up of presumptive lesions during medical therapy and in identification of clinically unsuspected lesions deserving further investigation, it cannot distinguish tuberculomas from other intracranial mass lesions $(16,25)$. MRI is believed to be more specific in diagnosing tuberculomas than CT scan, but not always with accuracy $(26,28,29$, 34). Therefore, a definitive diagnosis usually relies on positive histological findings. Such a confirmation is recommended before starting antituberculous treatment $(14,15,22,24,25)$ and radiological methods can be used in monitoring the response to antituberculous treatment in patients with histologically confirmed tuberculomas $(25,26$,
34). A proposed algorithm for the management of suspected tuberculomas are given in Figure 2.

Initial management of intracranial tuberculoma aims to reduce intracranial pressure and other mass effects, and to confirm the diagnosis. There is still debate as to the most appropriate therapeutic approach. Diagnosis based on neuroimaging followed by empiric antituberculous treatment (32, 35) with or without open surgical approach (6) is common. In recent years, image-guided stereotactic surgery has been added to these existing forms of treatment $(22,23,25)$. Most cases respond well to antituberculous treatment, although in some paradoxical progression of the lesions has been noted $(14,15,37)$. However, antituberculous agents have a number of side effects $(3,6,14,15)$. Indeed, there is no consensus regarding the duration of treatment for intracranial tuberculomas and the combination of drugs used for ATT is not standardized but patients are prescribed a minimum of three drugs. An extended CT or MRI guided treatment with second-line agents is recommended with or without addition of corticosteroids, in case of resistance $(14,15,20,24)$. However, none of our patients required second-line agents or addition of corticosteroids.

An earlier cure has been reported in patients undergoing surgical treatment (24). Although open surgical treatment is successful in a number of cases, it presents the disadvantage of being a major procedure with associated surgical trauma risk in an already edematous brain. This is particularly important for the tuberculomas with critical intracranial localization (6). Moreover, it is poorly applicable in cases of multiple tuberculomas deeply seated in eloquent regions, and in poor surgical candidates who are too debilitated for general anesthesia $(23,25)$.

By the development of modern imaging systems, CT-guided stereotactic biopsy and microsurgery has gained popularity all over the world. The clinical use of stereotactic technique and apparatus for intracerebral surgery was first described by Leksell (21). This is a convenient technique with a high degree of precision, in which the location of the target and the position of the instrument are determined by the aid of X-rays. Initially stereotactic surgery was performed by the guidance of direct $X$ ray images; however, the procedure became safer 


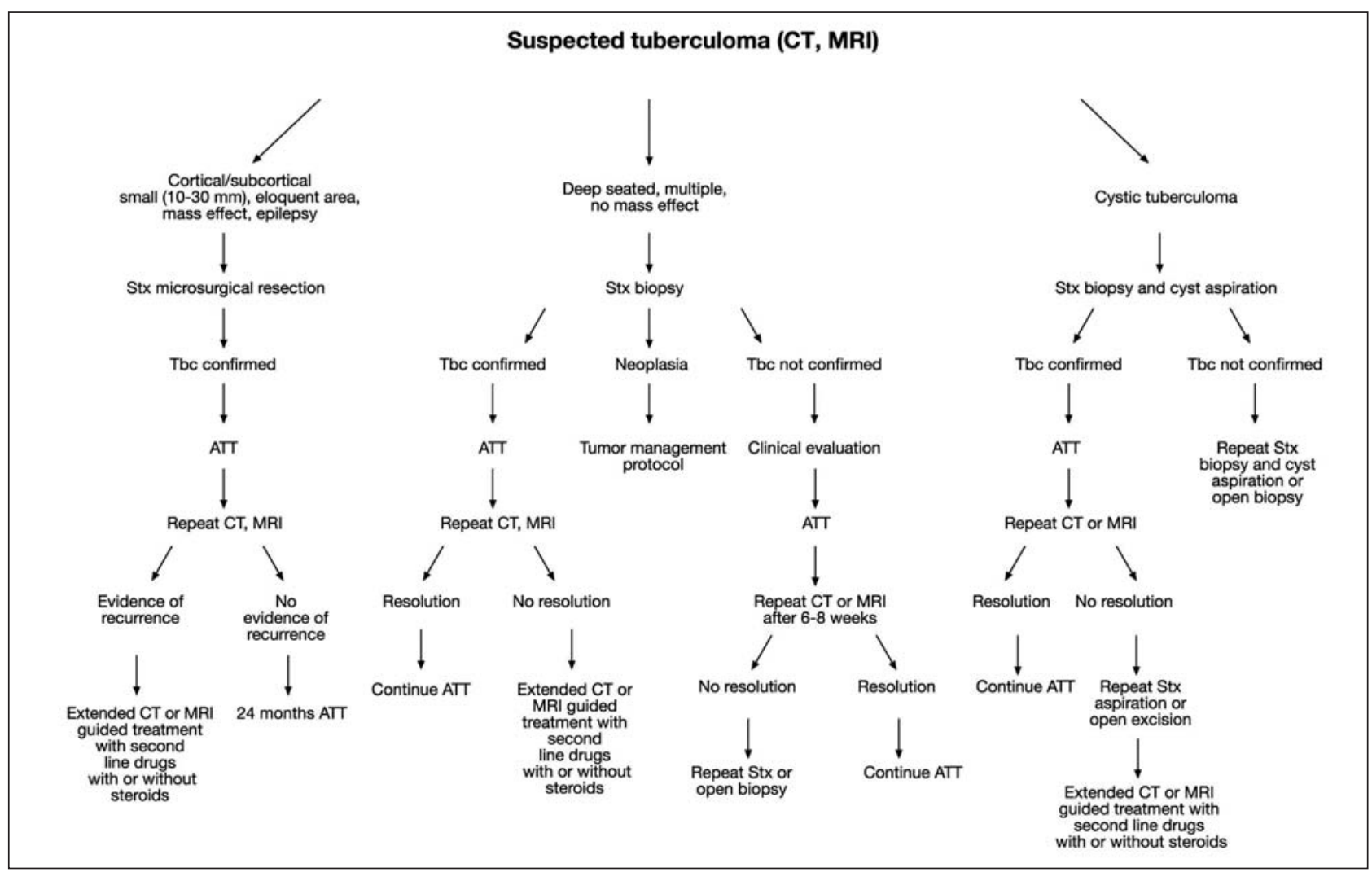

Figure 2: A suggested algorithm for the management of suspected tuberculomas.

and less invasive by the virtue of modern neuroimaging techniques $(1,2,8,10,17,21,25)$. It is minimally invasive, carries minimal morbidity and mortality risk, and can be performed on compromised patients under local anesthesia; thus, offering a safer alternative to conventional open surgery for obtaining a tissue diagnosis from intracranial masses, particularly when they are deep-seated $(1,2,7,8,10,12,17,22,25,33,36)$. Since the lesion itself responds well to antituberculous treatment and the major aim in most patients is to obtain a diagnosis, an intracranial tuberculoma may represent an ideal situation for management with this modality, if provided that there is no lifethreatening rise in intracranial pressure $(22,23,25)$.

Reports on the use of CT-guided stereotaxy in the management of intracranial tuberculomas are relatively scarce. In 1993, Rajshekkar and Chandy were the first to report on the management of intracranial tuberculomas by CT-guided stereotactic surgery (25) and in 1999, Mohanty et al. presented their experience on the diagnosis of intracranial tuberculomas by CT-guided stereotactic biopsy (22). This paper deals with the first 13 intracranial tuberculoma cases reported from Turkey that were managed using stereotactic methods. In our intracranial tuberculoma patients, antituberculous treatment was not given before an attempt to confirm the diagnosis histologically. Masses with radiological and clinical evidence of intracranial tuberculoma were either biopsied or excised using stereotactic methods and histological confirmation was possible in all but one patient. No procedurerelated mortality or permanent disability was observed. On the other hand, imaging methods were used for initial evaluation and for the evaluation of response to antituberculous treatment, rather than as a tool for definitive diagnosis.

Due to the following reasons, we preferred CTguided stereotactic microsurgical excision to closed biopsy for small superficial masses: (i) possibility of hemorrhage from superficial cortical vessels during closed biopsy of tuberculoma, which is a rather firm mass (25); (ii) greater chance of definitive diagnosis owing to the larger sample size obtained by excisional biopsy (25); (iii) to control symptoms like seizures and shorten the duration of antituberculous treatment $(9,24)$. In the present study, patients that 


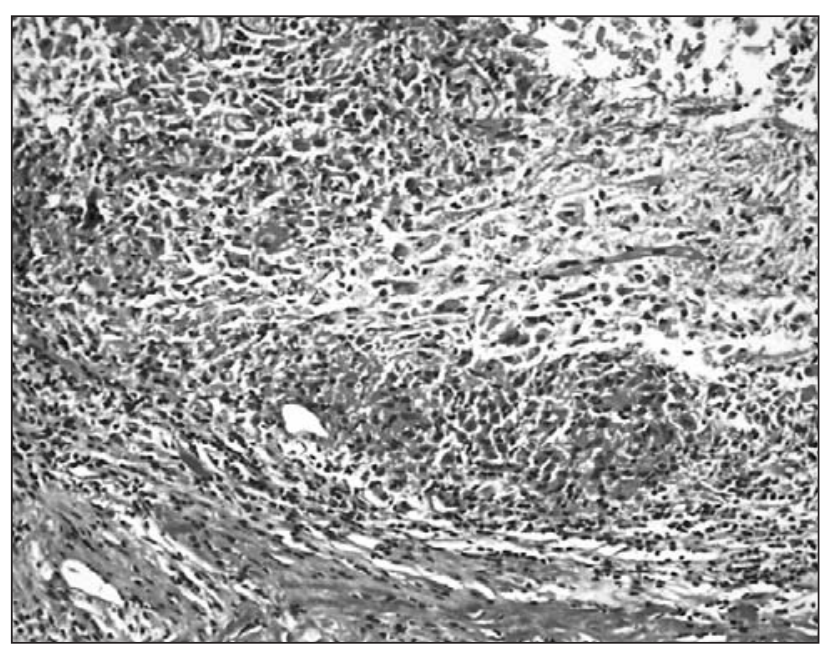

Figure 3: A small granuloma formation with minimal necrosis. (HEE staining $x 100)$.

underwent mass excision required shorter duration of ATT compared to biopsied patients. Histopathological diagnosis of tuberculoma could be established in all patients that underwent resection.

For deep-seated cystic intracranial tuberculomas, stereotactic aspiration may provide rapid and safe decompression, thus representing a suitable treatment modality (23). Although successful in a number of cases $(13,27)$, open surgical excision has several disadvantages in this setting. It is not suitable, particularly when the lesion is located in association with critical structures, since the procedure itself causes excessive surgical trauma in an already edematous brain. Moreover, it is far from being suitable for cases with multiple abscesses, for deeply seated abscesses in eloquent regions, and for poor surgical candidates too debilitated for general anesthesia (23). Thus, stereotactic aspiration is becoming more and more accepted in the management of cystic intracranial tuberculomas, since it can be performed with minimal risks, causes only slight trauma to the brain tissue, and is superior to other methods in challenging cases (i.e. multiple and / or deeply seated tuberculous abscesses) (23). In the present study, one patient with cystic tuberculoma located in the third ventricle and presenting with raised intracranial pressure was biopsied and successfully aspirated at the same session using CT-guided stereotaxy.

However, there are certain limitations to the use of CT-guided stereotactic techniques in the setting of tuberculomas. These lesions are relatively hard and it is usually not easy to cut them even at open surgery. Since the probes used in stereotactic surgery are blunt tipped, they may fail to penetrate the thick capsule of the tuberculoma and instead may push away the mass. Even if the capsule is entered, the biopsy cup forceps may not be able to bite into the tough content of the mass $(22,23,25,30)$. Considering these structural features of tuberculomas, lesions suitable for resection were preferentially excised totally and only unsuitable lesions were biopsied. A spiral needle was used when a sufficient amount of biopsy sample could not be obtained by the sedan needle. As previously reported, we also encountered difficulties in obtaining biopsy samples and frequently multiple sampling attempts were required $(22,25,30)$. However, definitive diagnosis was possible in 12 out of 13 cases $(92 \%)$, which is in line with previous reports $(22,25)$. No procedure related complications occurred except for one case of self-limiting hemorrhage.

Only small series of intracranial tuberculoma patients managed by stereotactic approach have been reported so far. Although the number of patients is also small in our study, our results further support the view that CT-guided stereotactic surgery of intracranial tuberculomas, either for biopsy or resection, has several advantages over other methods. This surgical method has the potential to become the first-line modality, particularly as a diagnostic tool, in the management of intracranial tuberculomas.

\section{REFERENCES}

1. Apuzzo ML, Chandrasoma PT, Cohen D, Zee CS, and Zelman $\mathrm{V}$ : Computed imaging stereotaxy: Experience and perspective related to 500 procedures applied to brain masses. Neurosurgery 20: 930-937, 1987

2. Apuzzo ML, Sabshin JK: Computed tomographic guidance stereotaxis in the management of intracranial mass lesions. Neurosurgery 12: 277-285, 1983

3. Bayindir C, Mete O, Bilgic B: Retrospective study of 23 pathologically proven cases of central nervous system tuberculomas. Clin Neurol Neurosurg 108: 353-357, 2006

4. Behari S, Shinghal U, Jain M, Jaiswal AK, Wadwekar V, Das $\mathrm{KB}$, Jha S: Clinicoradiological presentation, management options and a review of sellar and suprasellar tuberculomas. J Clin Neurosci 16:1560-1566, 2009

5. Bernaerts A, Vanhoenacker FM, Parizel PM, Van Goethem JW, Van Altena R, Laridon A, De Roeck J, Coeman V, De Schepper AM: Tuberculosis of the central nervous system: Overview of neuroradiological findings. Eur Radiol 13: 1876-1890, 2003 
6. Bouchama A, al-Kawi MZ, Kanaan I, Coates R, Jallu A, Rahm $\mathrm{B}$, and Siqueira EB: Brain biopsy in tuberculoma: The risks and benefits. Neurosurgery 28: 405-409, 1991

7. Cabbell KL, Ross DA: Stereotactic microsurgical craniotomy for the treatment of third ventricular colloid cysts. Neurosurgery 38: 301-307, 1996

8. Calisaneller T, Ozdemir O, Ozger O, Ozen O, Kiyici H, Caner $\mathrm{H}$, Altinors $\mathrm{N}$ : The accuracy and diagnostic yield of computerized tomography guided stereotactic biopsy in brain lesions. Turk Neurosurg 18: 17-22, 2008

9. Chandy MJ, Rajshekhar V, Ghosh S, Prakash S, Joseph T, Abraham J, Chandi SM: Single small enhancing CT lesions in Indian patients with epilepsy: cClinical, radiological and pathological considerations. J Neurol Neurosurg Psychiatry 54: 702-705, 1991

10. Cosgrove GR, Steiner L: Stereotactic microsurgical resection of cerebral lesions. Stereotact Funct Neurosurg 61: 182-194, 1993

11. Dolin PJ, Raviglione MC, Kochi A: Global tuberculosis incidence and mortality during 1990-2000. Bull World Health Organ 72: 213-220, 1994

12. Edner G: Stereotactic biopsy of intracranial space occupying lesions. Acta Neurochir (Wien) 57: 213-234, 1981

13. Gonzalez PR, Herrero CV, Joachim GF, Ocana CR, Sevilla GC, Loyzaga PG: Tuberculous brain abscess. Case report. J Neurosurg 52: 419-422, 1980

14. Hejazi N, Hassler W: Multiple intracranial tuberculomas with atypical response to tuberculostatic chemotherapy: Literature review and a case report. Infection 25: 233-239, 1997

15. Hejazi N, Hassler W: Multiple intracranial tuberculomas with atypical response to tuberculostatic chemotherapy: Literature review and a case report. Acta Neurochir (Wien) 139: 194-202, 1997

16. Hirsh LF, Lee SH, Silberstein SD: Intracranial tuberculomas and the CAT scan. Acta Neurochir (Wien) 45: 155-161, 1978

17. Kelly PJ: Stereotactic surgery: What is past is prologue. Neurosurgery 46: 16-27, 2000

18. Kelly PJ: Volumetric stereotactic surgical resection of intraaxial brain mass lesions. Mayo Clin Proc 63: 1186-1198, 1988

19. Kelly PJ, Goerss SJ, Kall BA: The stereotaxic retractor in computer-assisted stereotaxic microsurgery. Technical note. J Neurosurg 69: 301-306, 1988

20. Kumar R, Prakash M, Jha S: Paradoxical response to chemotherapy in neurotuberculosis. Pediatr Neurosurg 42: 214-222, 2006

21. Leksell L: A stereotaxic apparatus for intracerebral surgery. Acta Chir Scand 99: 229-233, 1949

22. Mohanty A, Santosh V, Anandh B, Kolluri VR, Vasudev MK, Hegde T, Shankar SK: Diagnostic efficacy of stereotactic biopsies in intracranial tuberculomas. Surg Neurol 52: 252257; discussion 257-258, 1999
23. Mohanty A, Venkatarama SK, Vasudev MK, Khanna N, and Anandh B: Role of stereotactic aspiration in the management of tuberculous brain abscess. Surg Neurol 51: 443-446;1999

24. Poonnoose SI,Rajshekhar V: Rate of resolution of histologically verified intracranial tuberculomas. Neurosurgery 53: 873-878, 2003

25. Rajshekhar V, Chandy MJ: CT-guided stereotactic surgery in the management of intracranial tuberculomas. Br J Neurosurg 7: 665-671, 1993

26. Rajshekhar V, Haran RP, Prakash GS, Chandy MJ: Differentiating solitary small cysticercus granulomas and tuberculomas in patients with epilepsy. Clinical and computerized tomographic criteria. J Neurosurg 78: 402-407, 1993

27. Sandhyamani S, Roy S, Bhatia R: Tuberculous brain abscess. Acta Neurochir (Wien) 59: 247-256, 1981

28. Semlali S, El Kharras A, Mahi M, Hsaini Y, Benameur M, Aziz N, Chaouir S, Akjouj S: Imaging features of CNS tuberculosis. J Radiol 89: 209-220, 2008

29. Sonmez G, Ozturk E, Sildiroglu HO, Mutlu H, Cuce F, Senol MG, Kutlu A, Basekim CC, Kizilkaya E: MRI findings of intracranial tuberculomas. Clin Imaging 32: 88-92, 2008

30. Soo TM, Bernstein M, Provias J, Tasker R, Lozano A, Guha A: Failed stereotactic biopsy in a series of 518 cases. Stereotact Funct Neurosurg 64: 183-196, 1995

31. Tandon PN, Bhargava S: Effect of medical treatment on intracranial tuberculoma--a CT study. Tubercle 66: 85-97, 1985

32. Thwaites G, Fisher M, Hemingway C, Scott G, Solomon T, Innes J: British Infection Society guidelines for the diagnosis and treatment of tuberculosis of the central nervous system in adults and children. J Infect 59: 167-187, 2009

33. Tobler WD, Stanley M: Stereotactic resection of brain metastases in eloquent brain. Stereotact Funct Neurosurg 63: 38-44, 1994

34. Vasudev MK, Jayakumar PN, Srikanth SG, Nagarajan K, Mohanty A: Quantitative magnetic resonance techniques in the evaluation of intracranial tuberculomas. Acta Radiol 48: 200-206, 2007

35. Vengsarkar US, Pisipaty RP, Parekh B, Panchal VG, Shetty MN: Intracranial tuberculoma and the CT scan. J Neurosurg 64: 568-574, 1986

36. Yamada K, Goto S, Kochi M, Ushio Y: Stereotactic biopsy for multifocal, diffuse, and deep-seated brain tumors using Leksell's system. J Clin Neurosci 11: 263-267, 2004

37. Zorn-Olexa C, Laugel V, Martin Ade S, Donato L, Fischbach M: Multiple intracranial tuberculomas associated with partial status epilepticus and refractory infantile spasms. J Child Neurol 23: 459-462, 2008 